\title{
Characterization and Pathogenicity of Fusarium oxysporum Associated with Carya illinoinensis Seedlings
}

\author{
Tales Poletto ${ }^{1}$ (1) 0000-0002-6162-4445 \\ Marlove Fátima Brião Muniz ${ }^{1}$ (1) 0000-0001-7436-9589 \\ Vinícius Spolaor Fantinel ${ }^{1}$ (1) 0000-0002-0414-7486 \\ Ricardo Harakava ${ }^{2}$ (1) 0000-0003-1431-2665 \\ Jéssica Mengue Rolim ${ }^{3}$ (1) 0000-0003-2737-7599
}

\begin{abstract}
Pecan cultivation in Brazil has gained increasingly economic importance in the southern part of the country. The objective of this work was to identify the pathogen that causes root rot in Carya illinoinensis seedlings in the nursery, through morphological, molecular and pathogenicity tests. Fungi from the genus Fusarium found in symptomatic roots of pecan seedlings were isolated in potato dextrose agar (PDA) culture medium and purified. Morphological characterization was performed in PDA and carnation leaf agar (CLA) media. For the molecular characterization, the genomic segments ITS (internal transcribed spaces), $\beta$-tub (beta-tubulin), and tef1- $\alpha$ (elongation fact 1-alpha) were sequenced. The pathogenicity test was performed on healthy seedlings in the greenhouse. The combination of morphological and molecular characters was fundamental for identification of the species, showing that the most suitable genes for identification were ITS and tef1-a. The causative agent of root rot in C. illinoinensis seedlings in the nursery was identified as Fusarium oxysporum.
\end{abstract}

Keywords: etiology, root rot, pecan.

\section{INTRODUCTION AND OBJECTIVES}

Pecan [Carya illinoinensis (Wangenh.) Koch], belongs to Juglandaceae family. It is a deciduous tree native to temperate zones of North America, which was introduced in Brazil in 1870 with commercial interests (Poletto, Muniz, Poletto, Stefenon et al., 2015; Poletto et al., 2016). The most extensive plantations are located in the Vale do Taquari, Rio Pardo, and central regions of Rio Grande do Sul state (Poletto, Muniz, Poletto, Baggiotto, 2015).

Currently, the cultivation of this species for nut production has gained increasingly importance, mainly in the states of Rio Grande do Sul, Santa Catarina, and Paraná, because of its great acceptance by consumers, producers, and industries. According to data from IBGE (2016) in the year 2015, Rio Grande do Sul produced 2,498,000 kg of fruit, making up to $48 \%$ of the national production, with an estimated production value of $\mathrm{R} \$ 19,451,000.00$. Even with such a large production, this amount does not supply the national demand, and Brazil has to import most of what is consumed in the country.

As a result of this expansion, a new productive chain is being established in the country. Several sectors of the economy linked to nut production offer products and services for pecan cultivation. One of these sectors, which is constantly growing, is the production of seedlings. This sector is composed by several small and medium nurseries, which increase the production each year in order to supply the market demand.

In the nurseries, the production of pecan seedlings is carried out exclusively by seeds (rootstocks) which, after reaching the appropriate size, are grafted with selected cultivars (Poletto, Muniz, Poletto, Baggiotto, 2015). However, the seedlings suffer from diseases, specially root rot caused by fungi of the Fusarium genus. This disease was first reported in pecan in Brazil in 2014, and the causative agent was identified as

\footnotetext{
${ }^{1}$ Universidade Federal de Santa Maria (UFSM), Santa Maria, RS, Brasil

${ }^{2}$ Instituto Biológico de São Paulo, São Paulo, SP, Brasil

${ }^{3}$ Universidade Federal de Pelotas (UFPel), Pelotas, RS, Brasil
} 
Fusarium equiseti (Lazarotto, Muniz et al., 2014). However, isolates from Fusarium sp. with distinct characteristics have been observed associated with this disease in pecan.

Root rot is a disease caused by non-specific pathogens and, in the case of the Fusarium genus, its geographical distribution is extensive and has been reported in several crops. Fusarium subglutinans was diagnosed damaging Pinus taeda roots (Silva et al., 2017); F. sambucinum was reported causing seed rot and damping off in Pinus elliottii seedlings (Maciel et al., 2013); and F. lacertarum caused damage to casuarina (Casuarina equisetifolia) seedlings (Poletto, Maciel et al., 2015). Analyzing seeds of C. illinoinensis, Poletto et al. (2014) reported that fungi of the Fusarium genus were found associated with kernel in high percentages, and incidence reduction was not observed even after disinfestation (alcohol $70 \%$ for $2 \mathrm{~min}$ and then $\mathrm{NaClO}$ at $1 \%$ for $5 \mathrm{~min}$ ). Terabe et al. (2008) reported the occurrence of Fusarium sp. in 100\% of the samples of kernels and pecan shells, evidencing that this fungus may infect the seed and cause damage to seedlings in nursery due to the hot and humid conditions, favorable for its development.

Carneiro (1987) points out that the seeds are contaminated by several pathogens in the field and in subsequent operations, as harvesting, drying, and processing. They can affect seed quality reducing germination capacity, as well as causing seedling damping-off and root rot. The incidence of pathogens of the Fusarium genus has increased, causing losses in the production of seedlings and in the quality of the final product. Preliminary observations showed the presence of this fungus associated with lesions in the roots. In this context, this study aimed to identify the pathogen that causes root rot in C. illinoinensis seedlings in the nursery, through morphological, molecular, and pathogenicity tests.

\section{MATERIALS AND METHODS}

\subsection{Isolates obtainment}

To obtain the pathogen isolates, symptomatic seedlings produced in a greenhouse were collected in a nursery in the municipality of Santa Maria-RS and transported to the Phytopathology Laboratory of the Federal University of Santa Maria. Roots with lesions were disinfested with 1\% sodium hypochlorite and washed twice in sterile distilled water. Subsequently, they were transferred to Gerbox ${ }^{\circledR}$ boxes, placed in a humid chamber, incubated at $25^{\circ} \mathrm{C} \pm 2{ }^{\circ} \mathrm{C}$ and maintained with a photoperiod of $12 \mathrm{~h}$ for six days. After incubation, the samples were examined under a microscope with the preparation of microscopic slides for visualization of the pathogen structures. Portions of mycelium were transferred to Petri dishes containing potato dextrose agar (PDA) culture medium and incubated at $25^{\circ} \mathrm{C} \pm 2{ }^{\circ} \mathrm{C}$ under a 12 -hour photoperiod for seven days. The colonies developed in PDA were purified according to the monosporic culture technique described by Fernandes (1993). In total, six pure isolates of Fusarium sp. were obtained.

\subsection{Morphological characterization}

For evaluation of mycelial growth and colony color of the six isolates, disks ( $5 \mathrm{~mm}$ ) of PDA medium containing mycelium were transferred to the center of the Petri dish $(90 \mathrm{~mm})$ containing the same culture medium. The plates were incubated at $25^{\circ} \mathrm{C} \pm 2{ }^{\circ} \mathrm{C}$ under a 12 -hour photoperiod. The mycelial growth was estimated through the daily measurement of the colony diameter, with the aid of a digital caliper. Two measurements were taken in diametrically opposite directions. Measurements were performed for seven days as the colony grew throughout the entire plate. The colony color was evaluated based on the Munsell Soil Color Chart (Munsell Color, Grand Rapids, MI, USA).

For the characterization of the reproductive structures of the isolates, a portion of mycelium was transferred to the carnation leaf agar (CLA) culture medium. The type of phialides, presence or absence of chlamydospores and microconidia, size, shape, and number of septa of macroconidia, and coloration of sporodochia were evaluated. After seven days of growth, slides were prepared to visualize the structures under an optical microscope. To determine the size of conidia (length and width), thirty conidia were measured using a 10× magnification eyepiece (Nikon YS-Cf 10X/18) coupled to an Olympus BX $41^{\circledR}$ contrast microscope in the $40 \times$ objective. Morphological identification was performed according to the classification keys of Nelson et al. (1983), Leslie \& Summerell (2006), and Gerlach \& Nirenberg (1982). The isolates of Fusarium sp. presented similar morphological characteristics and, according to the literature, were considered as belonging to the same species. Therefore, a sample was selected for molecular characterization and pathogenicity tests.

\subsection{Molecular characterization}

For genomic DNA isolation, portions of mycelium were removed from a monosporic culture grown in PDA medium for five days using the CTAB method (Doyle \& Doyle, 1990). The extracted genomic DNA samples were subjected to the polymerase chain reaction (PCR) for the amplification of the internal transcribed spacer (ITS), elongation factor 1-alpha (tef1- $\alpha)$, and beta-tubulin ( $\beta$-tub) (Table 1$)$. 
Table 1. Primers used in this study.

\begin{tabular}{cccc} 
Locus & \multicolumn{2}{c}{ Primers sequences } & References \\
Internal transcribed spacer (ITS) & & White et al., 1990 \\
ITS1 & TTCCGTAGGTGAACCTGCGG & \\
ITS4 & TCCTCCGCTTATTGATATGC & \\
Transcriptional elongation factor $($ tef1- $\alpha)$ & & \\
EF1-T & ATGGGTAAGGARGACAAGAC & Rehner \& Buckley, 2005 \\
EF1-1567R & ACHGTRCCRATACCACCRATCTT & \\
Beta-tubulin $(\boldsymbol{\beta}$-tub) & & Developed by Instituto \\
BTUB-F 35 & AAGGGHCAYTAYACYGARGG & Biológico de São Paulo \\
BTUB-R & CATGTTGGACTCDGCCTC & - SP &
\end{tabular}

The PCR mix contained approximately $30 \mathrm{ng}$ of DNA, $10 \times$ buffer, $2.5 \mu \mathrm{l}$ of each dNTP, $20 \mathrm{nM} \mathrm{MgCl}_{2}, 25 \mathrm{nM}$ of each primer and 5.0 U of Taq-DNA polymerase. Amplification was carried out in a thermocycler MJ Research PTC-100 MT under the following cycle conditions: $94^{\circ} \mathrm{C}$ for $2 \mathrm{~min}$, thirty cycles of $94{ }^{\circ} \mathrm{C}$ for $45 \mathrm{~s}, 55^{\circ} \mathrm{C}$ for $30 \mathrm{~s}, 72{ }^{\circ} \mathrm{C}$ for $35 \mathrm{~s}$ and $72{ }^{\circ} \mathrm{C}$ for $10 \mathrm{~min}$. At the end of the reaction, the PCR products were maintained at $4{ }^{\circ} \mathrm{C}$. A negative control without DNA was included in the PCR amplification. Amplified fragments and control were separated using $1.2 \%$ agarose gel electrophoresis in $1 \times$ TBE buffer $(10.8 \mathrm{~g}$ of tris base, $5.5 \mathrm{~g}$ of boric acid, $4 \mathrm{ml}$ of $0.5 \mathrm{M}$ EDTA and $4 \mathrm{ml}$ of distilled water), stained with ethidium bromide and visualized under ultraviolet light. PCR products were purified with 13\% Polyethylene Glycol (PEG) 8000 for further sequencing.

Sequencing was performed on a Mega BACE 500 (Amersham) sequencing system. The sequenced fragments were analyzed using the BioEdit program (Hall, 1999). The obtained nucleotide sequences were compared with those deposited in the GenBank database. GenBank sequences that presented the highest scores were selected and aligned along with the obtained sequences using the ClustalW algorithm. Additionally, a phylogenetic analysis was conducted using the neighbor-joining method with 1000 bootstrap replicates as performed in the Mega program version 4 (Tamura et al., 2007). The similarity of the nucleotide sequences among the isolates was calculated using the Basic Local Alignment Search Tool (Blast).

\subsection{Pathogenicity test}

For the pathogenicity test, freshly germinated healthy seedlings (four days) were used. To produce inoculum, Fusarium sp. was cultured for fifteen days in flasks containing $30 \mathrm{~g}$ of autoclaved rice (shelled, parboiled type) (30 min at $121^{\circ} \mathrm{C}$, at $1 \mathrm{~atm}$ ) and incubated at $25^{\circ} \mathrm{C} \pm 2{ }^{\circ} \mathrm{C}$ under a 12 -hour photoperiod. The inoculation occurred with the incorporation of $60 \mathrm{~g}$ of rice and the inoculum to the commercial substrate Mecplant ${ }^{\circledast}$ in plastic containers (5 liters), fifteen days before transplanting the seedlings. Ten seedlings were used for the pathogenicity test and other ten for the control treatment, which was inoculated only with sterile rice. The evaluation occurred after ninety days, and the symptomatic seedlings were taken to the laboratory to evaluate the pathogenicity, observing the presence of necrotic roots and reflected symptoms in the aerial part. Subsequently, the pathogen was re-isolated.

\section{RESULTS AND DISCUSSION}

\subsection{Symptoms of sickness in the nursery}

The occurrence of root rot in C. illinoinesis caused by Fusarium sp. was found in a nursery environment, at an early stage of development. The symptoms of the disease are noticed when there are yellowing and necrosis of the leaves with subsequent fall, growth stagnation, rotting/darkening of the roots and, in more advanced states, the death of the plant (Figure 1a). Some producers reported the occurrence of similar symptoms in plants already established in the field. However, in addition to the symptoms above described, the plants also present descending death of branches, dark stretch marks in the trunk vascular system, with subsequent death of the plant. To date, there is no information about relation of the symptoms above and the disease in question.

\subsection{Morphological characterization}

The colonies of the six isolates of Fusarium sp. cultivated in PDA medium presented similar characteristics, with initially white staining, later becoming light violet from the center towards the edges of the plate. The fungus presented a light pink colored aerial mycelium with an average daily mycelial growth of $2.5 \mathrm{~cm}$ (Figure 1c). 
Colonies grown in CLA medium produced abundant, weak orange sporodochia (Figure 1d). The colonies cultured in CLA also produced microconidia in the aerial mycelium, formed in short monophialides, in false heads or isolated, with oval to reniform shape (Figure 1f and 1g). Abundant presence of chlamydospores in the aerial mycelium was also observed, mainly isolated and presenting a rounded shape (Figure 1e). The macroconidia presented a sickleshaped form, usually with three to four septa, the apical cell most often curved and basal cell pedicellate. The size of the macroconidia ranged from 37.5-50 (42) $\mu \mathrm{m}$ in length by $5-6.3(5.5) \mu \mathrm{m}$ in width (Figure $1 \mathrm{~h}$ ). According to the used identification keys, the isolates were morphologically identified as F. oxysporum.

The morphological characteristics are of paramount importance for the characterization and identification of fungal species. For the Fusarium genus there are keys of taxonomic classification based on morphological characteristics such as described by Nelson et al. (1983), Leslie \& Summerell (2006), and Gerlach \& Nirenberg (1982), which consider the growth and coloration of colonies grown in PDA, the presence, shape and size of structures such as macro and microconidia, chlamydospores, exudates, phialides and sporodochia of the colonies in CLA medium. In association with morphological analysis, genetic methods are widely used in recognition studies of fungal species, because they are fast and accurate, giving more credibility to the identification process (Balajee et al., 2009).
The morphological characteristics observed in this work resemble those described by Poletto et al. (2010) and Poletto et al. (2012) for Fusarium oxysporum that causes root rot in yerba mate (Ilex paraguariensis). The clear violet coloration of the colonies was also verified by $\mathrm{Su} \& \mathrm{Fu}$ (2013) in isolates of root rot F. oxysporum in Pulsatilla koreana. Cao et al. (2013) observed root rot in licorice (Glycyrrhiza uralensis) caused by F. oxysporum and F. solani and noted that F. oxysporum monophialides are shorter when compared to F. solani. However, the size of macroconidia was different from that found by Su \& Fu (2013) and Pérez-Hernández et al. (2014) for F. oxysporum causing root rot in chillies (Capsicum annuum) and by Lazarotto, Milanesi et al., (2014) for F. oxysporum associated with root rot in Carya illinoinensis seedlings, which presented smaller dimensions [28.9-32.8 (30.8) $\mathrm{mm}$ long by 3.25-3.5 (3.3) $\mathrm{mm}$ wide].

Poletto et al. (2012) identified isolates of Fusarium spp. pathogenic to yerba mate using morphological characteristics and keys for taxonomic classification. Walker et al. (2016) also used classification keys with morphological criteria to identify isolates of Fusarium spp. pathogenic to guajuvira (Cordia americana). However, these authors confirmed the results through molecular techniques, sequencing genes such as ITS and tefl- $\alpha$. Therefore, the importance of the combination between morphological and genetic characters to identify Fusarium sp. is evident.
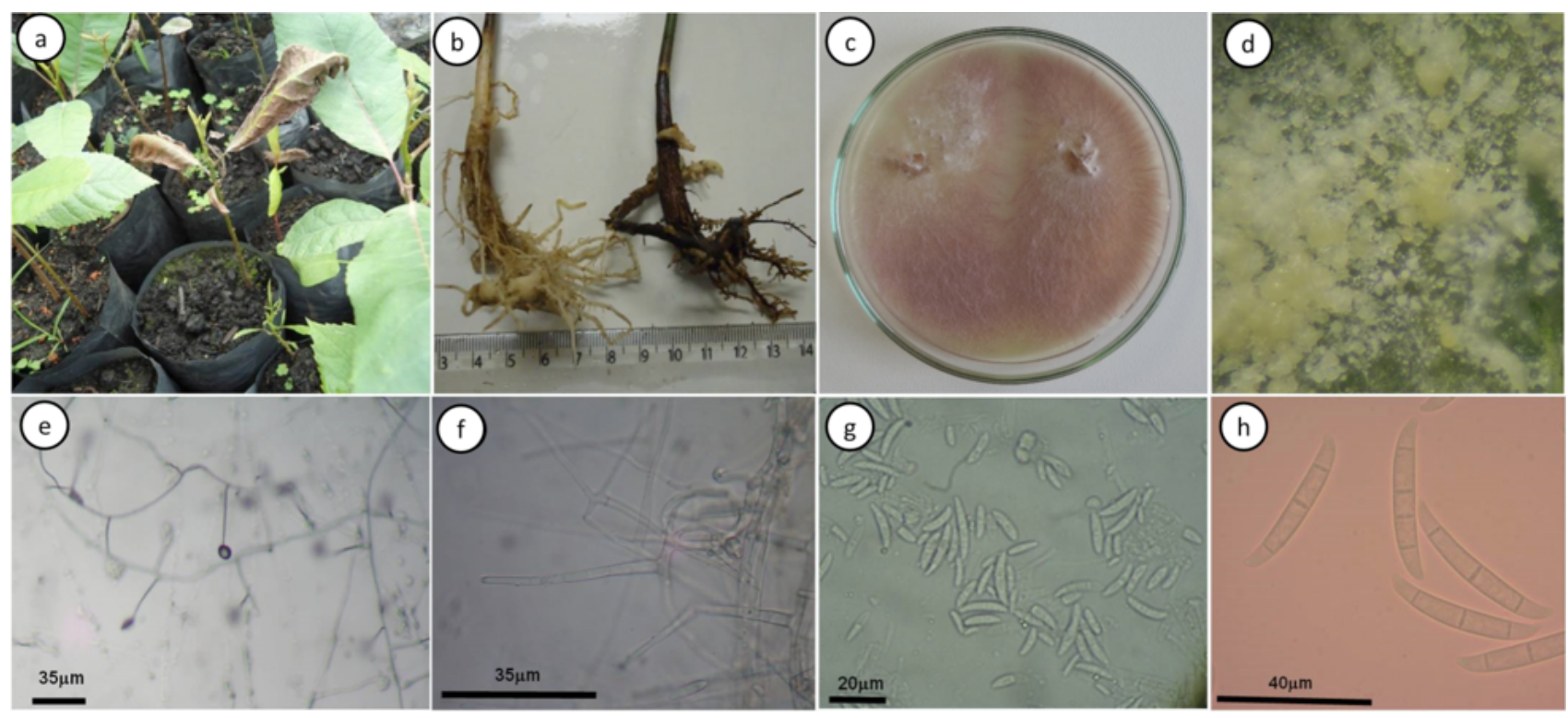

Figure 1. Morphological characteristics of Fusarium oxysporum. (a) Carya illinoinensis seedlings with root rot; (b) roots after pathogenicity test (left control, right inoculated); (c) culture on PDA medium; (d) sporodochia on CLA medium; (e) resistance structures (chlamydospores); (f) monophialides; (g) microconidia; (h) macroconidia. 


\subsection{Molecular characterization}

The most similar accessions and sequence coverage obtained from the Blast survey performed on GenBank's website, followed by its accession number, are presented in Table 2. These sequences were used to construct genetic similarity dendrograms.

In the phylogenetic dendrogram based on the ITS segment of Fusarium sp., along with the sequences' comparison (Figure 2), Fusarium sp. was allocated to the clade composed of three other Fusarium oxysporum sequences, which show high similarity (100\% JN222394, $100 \% \mathrm{KJ} 584542$, and 100\% KF907243). The bootstrap support value was $98 \%$ for the clade, indicating that this region of the DNA was efficient for discrimination of this species.
With the $\beta$-tub sequencing, lower coverage and similarity values were obtained, which reduces the reliability of the alignment and discrimination of the species. In the phylogenetic dendrogram it was possible to observe that the isolate of Fusarium sp. was allocated in the same clade as the species F. oxysporum and F. oxysporum f. sp. pisi. However, the bootstrap support value was low (50\%), being unreliable for species discrimination (Figure 2).

The phylogenetic dendrogram made with the sequencing of the genomic region of the tef 1 - $\alpha$ presented $100 \%$ bootstrap support for the clade where the Fusarium sp. sequence was allocated along with two other F. oxysporum sequences (MG557839 and KM025417) (Figure 2). In addition, the sequences comparison presented high percentages of coverage and similarity, which contributes to increasing the reliability of the alignment and the discrimination of the species.

Table 2. GenBank access, coverage and similarity of the species used in the construction of the phylogenetic dendrogram of the internal transcribed spacer (ITS) genomic region, $\beta$-tubulin ( $\beta$-tub), and elongation factor 1- $\alpha$ (tef1- $\alpha$ ).

\begin{tabular}{|c|c|c|c|}
\hline Species & GenBank access & Coverage (\%) & Similarity (\%) \\
\hline \multicolumn{4}{|c|}{ ITS } \\
\hline F. oxysporum & JN222394 & 100 & 100 \\
\hline F. oxysporum & KJ584542 & 99 & 100 \\
\hline F. oxysporum & KF907243 & 99 & 100 \\
\hline F. subglutinans & GU205425 & 97 & 99 \\
\hline F. bulbicola & GU205412 & 97 & 98 \\
\hline F. incarnatum & KJ652367 & 100 & 94 \\
\hline F. equiseti & KJ412508 & 99 & 94 \\
\hline F. chlamidosporum & KP230826 & 94 & 95 \\
\hline \multicolumn{4}{|c|}{$\beta$-tub } \\
\hline F. oxysporum & KJ001537 & 76 & 97 \\
\hline F. oxysporum f. sp. pisi & JQ265748 & 76 & 97 \\
\hline F. subglutinans & AB587057 & 76 & 96 \\
\hline F. bulbicola & KF466437 & 76 & 95 \\
\hline F. verticillioides & KJ020883 & 70 & 94 \\
\hline F. acutatum & U34431 & 66 & 94 \\
\hline F. begoniae & AY329044 & 68 & 96 \\
\hline F. concentricum & KF604012 & 70 & 95 \\
\hline \multicolumn{4}{|c|}{ tef1- $\alpha$} \\
\hline F. oxysporum & MG557839 & 98 & 99 \\
\hline F. oxysporum & KM025417 & 97 & 99 \\
\hline F. commune & KC820971 & 94 & 95 \\
\hline F. acutatum & JF 740744 & 98 & 93 \\
\hline F. proliferatum & KC 584856 & 98 & 93 \\
\hline F. subglutinans & KC 584839 & 96 & 93 \\
\hline F. denticulatum & KC 820969 & 98 & 92 \\
\hline F. mexicanum & KM 823587 & 96 & 92 \\
\hline
\end{tabular}



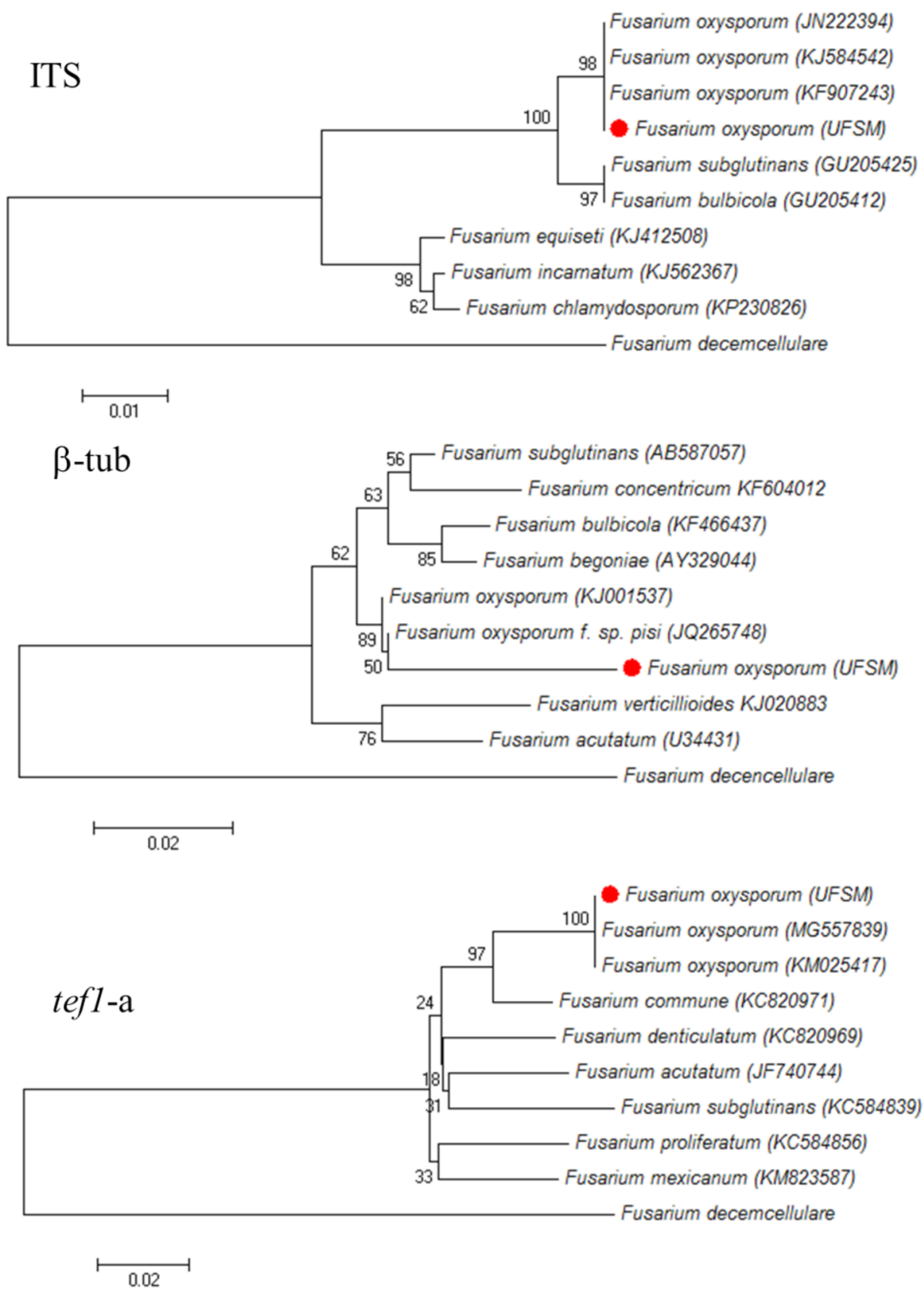

Figure 2. Phylogenetic dendrogram from DNA sequences of ITS, $\beta$-tub, and tef1- $\alpha$ regions, based on the neighbor-joining method. The numbers on branches indicate the bootstrap support after 1,000 repetitions.

Therefore, the sequencing of the ITS regions, $\beta$-tub, and tef1- $\alpha$ on the molecular analysis and the description of the morphological characteristics provide sufficient support to conclude that the agent of root rot in pecan seedlings is Fusarium oxysporum. ITS and tef1-a sequences of Fusarium oxysporum were deposited at the GenBank (accession numbers KR905680 and MG000154, respectively).

The pathogen identified in this study has been reported in several crops causing damage to plants. Gherbawy (1999) points out that F. oxysporum is a soil pathogen that causes disease in plants and has a wide distribution worldwide. In addition, the author reports that $F$. oxysporum is probably the species that causes the greatest economic damage to agricultural crops in comparison to any other plant pathogen.

Shrestha et al. (2016) diagnosed F. oxysporum causing rot in the stem and in the roots of cowpea (Vigna unguiculata) in Tennessee. In this study, the fungal species was identified through morphological and molecular characteristics by the sequencing of the tef1-a gene. F. oxysporum was also found to cause root rot and stem rot in cherry plants (Prunus avium) 
in British Columbia; the taxonomic classification of the species was performed comparing morphological and genetic characters by the ITS and tef1- $\alpha$ regions (Úrbez-Torres et al., 2016). Similarly, Pérez-Hernández et al. (2014) diagnosed F. oxysporum causing root rot in chili (Capsicum annuum). Fusarium oxysporum was also diagnosed in orchid (Dendrobium officinale) in China, causing root and stem decay. The fungus was identified by the sequencing of ITS, $\beta$-tub, and tefi- $\alpha$ genomic regions (Zhang et al., 2017).

According to Wunsch et al. (2009), F. oxysporum colonizes endophytic roots without causing disease symptoms, but usually colonizes roots pathogenically and contributes to rot in the root and in the stem, or colonizes the vascular system causing wilt and rapid death of plants. Gherbawy (1999) reports that the species F. oxysporum also presents several formae speciales, which are grouped according to the specificity of the host or group of hosts that they infect. Gordon et al. (2016) observed F. oxysporum causing wilt on blackberry plants in California. Banana wilt caused by Fusarium oxysporum f. sp. cubense is one of the most important diseases of the crop, which causes immense economic damages (Ingle \& Ingle, 2013).

\subsection{Pathogenicity test}

The seedlings inoculated with F. oxysporum showed the first symptoms ninety days after the beginning of the test. The associated symptomatology was similar to the original one found in plants with root rot. No change was observed in the control treatment plants (Figure 1b). Root samples with root rot symptoms obtained from inoculated seedlings, after being kept in moist chamber conditions at $25^{\circ} \mathrm{C} \pm 2{ }^{\circ} \mathrm{C}$ with a photoperiod of 12 hours for four days, presented fungal structures typical of Fusarium sp., indicating the colonization of the tissues by the pathogen. Subsequently, it was re-isolated to Petri dishes containing PDA medium, completing the Koch postulates.

The symptoms observed in the aerial part of the seedlings can be defined as reflect symptoms, since the damage caused by the pathogen in the roots impair the absorption of water and nutrients, disturbing the metabolism of the plant and, consequently, causing the symptoms. The results of this study corroborate those found by Cao et al. (2013) who observed that Chinese licorice seedlings (Glycyrrhiza uralensis) with root rot caused by F. oxysporum and F. solani showed an abnormality in the aerial part such as yellowing and subsequent falling of the leaves. The same occurred in yerba mate when the pathogens F. oxysporum and F. solani caused root rot in plants in the nursery and in the field; in addition to necrotic roots, yellowing, necrosis, and leaf drop occurred (Poletto et al., 2012). In the beetroot (Beta vulgaris) the pathogen
F. oxysporum, besides causing root necrosis, caused root vascular discoloration and foliar symptoms, including yellowing and inter-nerval wilting (Hanson \& Jacobsen, 2006). F. solani was also reported in iron walnut (Juglans sigillata) causing root rot, symptoms included drying of leaves and branches until the death of the plant. The original symptoms were reproduced in the pathogenicity test (Zheng et al., 2015).

Therefore, root rot is an important disease in pecan, since it harms the development of the seedlings in the nursery stage, causing economical losses to the nurserymen. Therefore, carrying out the correct diagnosis of the disease and knowing the characteristics of the pathogen is fundamental, since they provide subsidies for the development of disease control and prevention strategies, mainly involving studies with genetic resistance.

\section{CONCLUSIONS}

The combination of morphological and molecular characters was fundamental for the identification of the species, evidencing that the most appropriate genomic segments were ITS and tefl-a.

The causal agent of root rot in seedlings of Carya illinoinensis in nursery was identified as Fusarium oxysporum.

\section{ACKNOWLEDGEMENTS}

The authors thank the Coordenação de Aperfeiçoamento de Pessoal de Nível Superior (Capes) for the scholarship given for the first author. Also, the Conselho Nacional de Desenvolvimento Científico e Tecnológico (CNPq) for the research productivity scholarship given for Marlove Fátima Brião Muniz.

\section{SUBMISSION STATUS}

Received: 27 Oct. 2017

Accepted: 26 Aug. 2018

Associate editor: Natália Corniani

\section{CORRESPONDENCE TO}

\section{Tales Poletto}

Universidade Federal de Santa Maria, Av. Roraima, 1.000, CEP 97105-900, Santa Maria, RS, Brasil

e-mail: tecnicotales@hotmail.com

\section{REFERENCES}

Balajee SA, Borman AM, Brandt ME, Cano J, Cuenca-Estrella M, Dannaoui E et al. Sequence-based identification of Aspergillus, Fusarium, and Mucorales species in the clinical mycology laboratory: where are we and where should we go from here? Journal of Clinical Microbiology 2009; 47(4): 877-884. 10.1128/JCM.01685-08 
Cao XM, Cai J, Li SB, Zhang H, Lu ZQ, Hu XP. Fusarium solani and Fusarium oxysporum associated with root rot of Glycyrrhiza uralensis in China. Plant Disease 2013; 97(11): 1514. 10.1094/PDIS-12-12-1111-PDN

Carneiro JS. Teste de sanidade de sementes de essências florestais. In: Soave J, Wetzel MMVS, editors. Patologia de sementes. Campinas: Fundação Cargill; 1987. p. 363-393.

Doyle JJ, Doyle JL. Isolation of plant DNA from fresh tissue. Focus 1990; 12(1): 13-15.

Fernandes MR. Manual para laboratório de fitopatologia. Passo Fundo: Embrapa; 1993.

Gerlach W, Nirenberg H. The genus Fusarium: a pictorial atlas. Berlin: BBA; 1982.

Gherbawy YAMH. RAPD profile analysis of isolates belonging to different formae speciales of Fusarium oxysporum. Cytologia 1999; 64(3): 269-276.

Gordon TR, Kirkpatrick SC, Henry PM, Kong M, Broome JC. First report of a wilt disease of blackberry caused by Fusarium oxysporum in California. Plant Disease 2016; 100(5): 1018. 10.1094/PDIS-07-15-0784-PDN

Hall TA. BioEdit: a user-friendly biological sequence alignment editor and analysis program for Windows 95/98/NT. Nucleic Acids Symposium Series 1999; 41: 95-98.

Hanson LE, Jacobsen BJ. Beet root-rot inducing isolates of Fusarium oxysporum from Colorado and Montana. Plant Disease 2006; 90(2): 247. 10.1094/PD-90-0247A

Ingle A, Ingle R. Isolation and identification of Fusarium oxysporum infecting Musa plants in Maharashtra region and their molecular characterization. Asiatic Journal of Biotechnology Resources 2013; 4(1): 28-34.

Instituto Brasileiro de Geografia e Estatística - IBGE. Produção agrícola municipal 2015 [Internet]. Rio de Janeiro: IBGE; 2016 [cited 2017 July 5]. Available from: http://bit.ly/2ohyOCZ

Lazarotto M, Milanesi PM, Muniz MF, Reiniger LR, Beltrame R, Harakava R, Blume E. Morphological and molecular characterization of Fusarium spp pathogenic to pecan tree in Brazil. Genetics and Molecular Research 2014; 13(4): 9390-9402. 10.4238/2014.November.11.5

Lazarotto M, Muniz MFB, Santos RF, Blume E, Harakawa R, Hamann FA. First report of Fusarium equiseti associated on pecan (Carya illinoinensis) seeds in Brazil. Plant Disease 2014; 98(6): 847. 10.1094/PDIS-09-13-0976-PDN

Leslie J, Summerell BA. The Fusarium laboratory manual. Hoboken: Blackwell; 2006

Maciel CG, Muniz MFB, Milanesi PM, Lazarotto M, Blume E, Harakawa $\mathrm{R}$ et al. First report of Fusarium sambucinum associated on Pinus elliottii seeds in Brazil. Plant Disease 2013; 97(7): 995. 10.1094/PDIS-11-12-1045-PDN

Nelson PE, Toussoun TA, Marasas WF, editors. Fusarium species: an illustrated manual for identification. Philadelphia: Pennsylvania State University Press; 1983.

Pérez-Hernández A, Serrano-Alonso Y, Aguilar-Pérez MI, GómezUroz R, Gómez-Vázquez J. Damping-off and root rot of pepper caused by Fusarium oxysporum in Almería province, Spain. Plant Disease 2014; 98(8): 1159. 10.1094/PDIS-02-14-0212-PDN
Poletto I, Muniz MFB, Ceconi DE, Mezzomo R, Rodrigues J. Influência da inoculação de Fusarium spp e níveis de sombreamento no crescimento e desenvolvimento da erva-mate. Ciência Florestal 2010; 20(3): 513-521. 10.5902/198050982065

Poletto I, Lupatini M, Muniz MFB, Antoniolli ZI. Caracterização e patogenicidade de isolados de Fusarium spp. causadores de podridão-deraízes da erva-mate. Floresta 2012; 42(1): 95-104. 10.5380/rf.v42i1.26305

Poletto I, Muniz MFB, Ceconi DE, Poletto T. Aspectos epidemiológicos da podridão-de-raízes da erva-mate (Ilex paraguariensis). Ciência Florestal 2015; 25(2): 281-291. 10.5902/1980509818445

Poletto I, Muniz MFB, Poletto T, Stefenon VM, Baggiotto C, Ceconi DE. Germination and development of pecan cultivar seedlings by seed stratification. Pesquisa Agropecuária Brasileira 2015; 50(12): 1232-1235. 10.1590/S0100-204X2015001200014

Poletto T, Maciel CG, Muniz MFB, Blume E, Poletto T, Harakawa R, Bagiotto C. First report of Fusarium lacertarum causing damping-off in Casuarina equisetifolia in Brazil. Plant Disease 2015; 99(7): 1040. 10.1094/PDIS-12-14-1272-PDN

Poletto T, Muniz MFB, Baggiotto C, Ceconi DE, Poletto I. Fungos associados às flores e sementes da nogueira-pecã (Carya illinoinensis). Revista de Ciências Ambientais 2014; 8(1): 5-13. 10.18316/1384

Poletto T, Muniz MFB, Poletto I, Baggiotto C. Métodos de superação de dormência da semente de nogueira-pecã Carya illinoinensis (Wangenh.) K. Koch. Árvore 2015; 39(6): 1111-1118. 10.1590/0100-67622015000600014

Poletto T, Muniz MFB, Poletto I, Stefenon VM, Maciel CG, Rabusque JE. Dormancy overcome and seedling quality of pecan in nursery. Ciência Rural 2016; 46(11): 1980-1985. 10.1590/0103-8478cr20150835

Rehner SA, Buckley EA. Beauveria phylogeny inferred from nuclear ITS and EF1- $\alpha$ sequences: evidence for cryptic diversification and links to Cordyceps teleomorphs. Mycologia 2005; 97(1): 84-98. 10.1080/15572536.2006.11832842

Shrestha U, Ownley BH, Butler DM. First report of stem and root rot of cowpea caused by Fusarium oxysporum in Tennessee. Plant Disease 2016; 100(3): 649. 10.1094/PDIS-08-15-0934-PDN

Silva TWR, Santos AF, Auer CG, Tessmann DJ. Detection methods, transmission and pathogenicity of Fusarium spp. in Pinus taeda seeds. Ciência Florestal 2017; 27(1): 73-84. 10.5902/1980509826448

Su D, Fu JF. First report of root rot on Pulsatilla koreana caused by Fusarium oxysporum in China. Plant Disease 2013; 97(3): 425. 10.1094/PDIS-09-12-0849-PDN

Tamura K, Dudley J, Nei M, Kumar S. MEGA4: Molecular Evolutionary Genetics Analysis (MEGA) software version 4.0. Molecular Biology and Evolution 2007; 24(8): 1596-1599. 10.1093/molbev/msm092

Terabe NI, Martins CM, Homechin M. Microorganismo associados a frutos de diferentes cultivates de noz Pecan. Ciência e Agrotecnologia 2008; 32(2): 659-662. 10.1590/S1413-70542008000200049

Úrbez-Torres JR, Boulé J, Haag P, Hampson C, O'Gorman DT. First report of root and crown rot caused by Fusarium oxysporum on sweet cherry (Prunus avium) in British Columbia. Plant Disease 2016; 100(4): 855. 10.1094/PDIS-08-15-0932-PDN

Walker C, Maciel CG, Milanesi PM, Muniz MFB, Mezzomo R, Pollet CS. Caracterização morfológica, molecular e patogenicidade de Fusarium acuminatum e Fusarium verticillioides a Cordia americana. Ciência Florestal 2016; 26(2): 463-473. 10.5902/1980509822747 
White TJ, Bruns T, Lee S, Taylor JW. Amplification and direct sequencing of fungal ribosomal RNA genes for phylogenetics. In: Innis MA, Gelfand DH, Sninsky JJ, White TJ, editors. PCR protocols: a guide to methods and applications. New York: Academic Press; 1990. p. 315-322.

Wunsch MJ, Baker AH, Kalb DW, Bergstrom GC. Characterization of Fusarium oxysporum f. sp. loti Forma Specialis nov., a monophyletic pathogen causing vascular wilt of Birdsfoot Trefoil. Plant Disease 2009; 93(1): 58-66. 10.1094/PDIS-93-1-0058
Zhang YQ, Lin BY, Zou MY, Liang JX, Hu HQ. First report of Fusarium wilt of Dendrobium officinale caused by Fusarium oxysporum in China. Plant Disease 2017; 101(6): 1039. 10.1094/PDIS-09-16-1270-PDN

Zheng L, Peng Y, Zhang J, Ma WJ, Li SJ, Zhu TH. First report of Fusarium solani causing root rot of Juglans sigllata Dode in China. Plant Disease 2015; 99(1): 159. 10.1094/PDIS-08-14-0801-PDN 